\title{
Artelogie
}

artelogie Recherche sur les arts, le patrimoine et la littérature de l'Amérique latine

13 | 2019

Violeta Parra: authenticité, primitivisme et processus d'exotisme chez les artistes latino-américains.

\section{"Les Tapisseries Chiliennes de Violeta Parra." Perspectivas sobre una exposición realizada en el Museo de Artes Decorativas del Palacio del Louvre en 1964}

Dra. Daniela Fugellie

\section{OpenEdition}

\section{Journals}

Edición electrónica

URL: http://journals.openedition.org/artelogie/3153

DOI: $10.4000 /$ artelogie.3153

ISSN: 2115-6395

Editor

Association ESCAL

Referencia electrónica

Dra. Daniela Fugellie, «"Les Tapisseries Chiliennes de Violeta Parra." Perspectivas sobre una exposición realizada en el Museo de Artes Decorativas del Palacio del Louvre en $1964 »$, Artelogie [En línea], 13 | 2019, Publicado el 07 enero 2019, consultado el 01 mayo 2019. URL : http:// journals.openedition.org/artelogie/3153; DOI : 10.4000/artelogie.3153

Este documento fue generado automáticamente el 1 mayo 2019.

Association ESCAL 


\title{
"Les Tapisseries Chiliennes de Violeta Parra." Perspectivas sobre una exposición realizada en el Museo de Artes Decorativas del Palacio del Louvre en 1964
}

\author{
Dra. Daniela Fugellie
}

\section{Representaciones de la experiencia parisina ${ }^{1}$}

1 La historia de cómo Violeta Parra logró exponer sus trabajos en el Louvre ha sido narrada por diversos familiares, amigos y conocidos, y recogida en libros testimoniales (I. Parra, 2015a; Stambuk y Bravo, 2011; A. Parra, 2006). Con algunas variantes, la narración corresponde a la que ofrece el fotógrafo Sergio Larraín:

\footnotetext{
"Recuerdo cuando contaba cómo había llegado al museo. Tenía muchos trabajos y no sabía dónde exponerlos. Entonces fue a dar donde un señor y después que le explicó lo que quería, esta persona le dio una tarjeta con dos direcciones. Una de ellas decía calle tanto, número tanto y partió para allá. De repente se encontró frente a un enorme edificio y volvió a mirar el papel para ver si era el número que le habían dado. ¡Le habían dado la dirección del Louvre! Estaba ahí - me contaba parada con sus dos trenzas y sus rollos de tapices, sin ni una recomendación, sola, sola, con sus cositas debajo del brazo." (en Stambuk y Bravo, 2011: p. 125).
}

Una vez dentro del Louvre, Violeta Parra habría sido recibida por Michel Faré, director del museo, quien se manifestó interesado en su trabajo. Las narraciones de Ángel Parra, Enrique Bello y Tomás Lago, entre otros, concuerdan en señalar que la exposición fue anulada por la comisión responsable cuando Violeta Parra se encontraba ya inmersa en su preparación. Una emocional Violeta habría elevado sus argumentos y demandas ante Faré, quien finalmente intercedió para que la exposición se realizara en la fecha acordada 
(Stambuk y Bravo, 2011: p. 126; A. Parra, 2006: p. 177-179). Así, Tomás Lago, catedrático de Arte Popular en la Universidad de Chile, recordaba:

"Fue tan doloroso para Violeta, que ahí mismo se le cayeron las lágrimas, lloró de desesperación. Esa manera de recibir la negativa era algo que se salía de la norma, porque en los medios artísticos de prestigio internacional, sobre todo en los grandes centros como París, no cabían ni sentimentalismos ni lloriqueos. Pero en Violeta todo era tan espontáneo que sencillamente lloró delante de ese señor [...]" (en Stambuk y Bravo, 2011: p. 126).

Dentro de estas narraciones, destaca la caracterización de Violeta como una mujer inocente y espontánea, quien pese a haber vivido en París entre 1955 y 1957, y nuevamente desde 1962, aparentemente no habría sabido que el imponente edificio ubicado en la conocida Rue de Rivoli - que por lo demás se encontraba a una distancia prudente de su residencia en el Quartier Latin - era el Palacio del Louvre. La inocencia se condice con la descripción física "con sus dos trenzas" y sus "cositas debajo del brazo" proporcionada por Larraín, que alude a una mujer naïve, cuya obra - las "cositas" - sería ajena al mundo de las bellas artes en el que sorpresivamente se encontraba. Su otredad se manifiesta igualmente en el testimonio de Lago, donde el llanto espontáneo aparece como una reacción fuera de lugar en el medio artístico parisino.

4 Las dos trenzas y la espontaneidad pueden remitir a una infantilización de la artista, como también a su origen campesino, ambos conceptos vinculados a la representación de su obra visual como 'arte inocente' y por ende connotada como espontánea, auténtica y no intelectual. Aunque sin trenzas, la película biográfica de Andrés Wood Violeta se fue a los cielos (2011) presenta una imagen similar, donde una sorprendida Violeta porta sus obras precariamente embaladas al interior del Museo del Louvre, rodeada de las pinturas italianas de gran formato de la Grande Galerie.

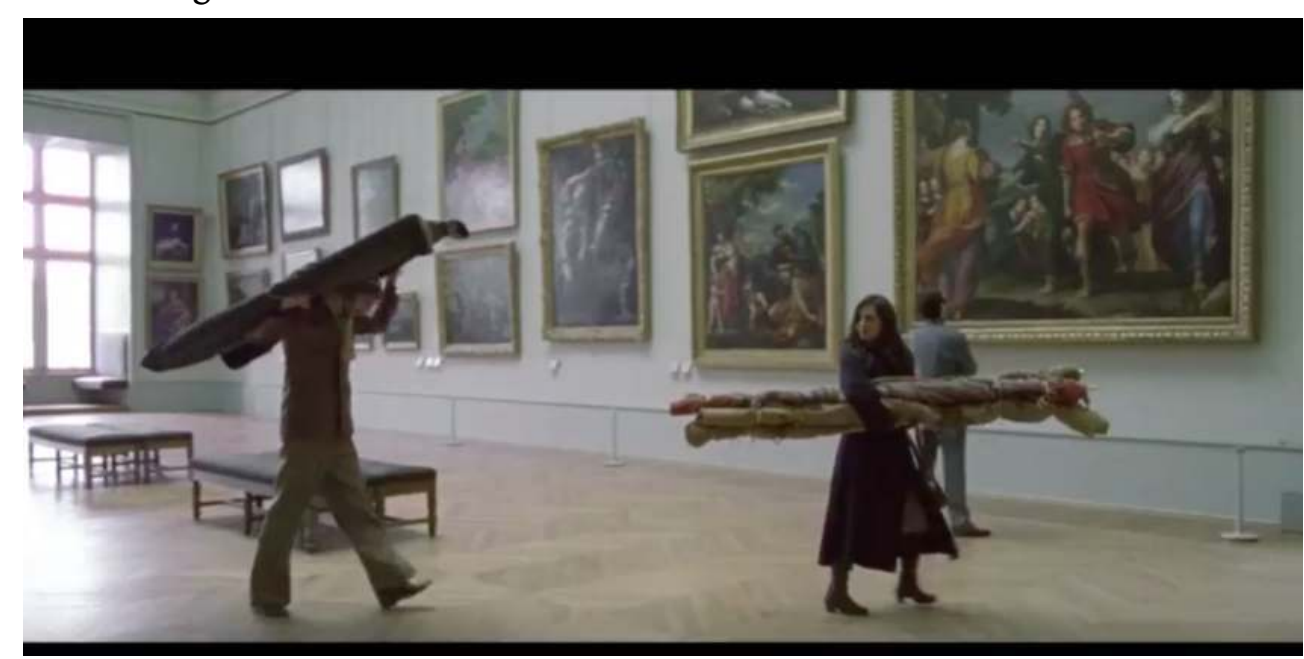

Imagen 1: Andrés Wood, Violeta se fue a los cielos (2011). Violeta y Ángel Parra en el Museo del Louvre. Fuente: Trailer oficial.

5 En la visión de sus contemporáneos chilenos, el discurso de la inocencia del arte de Violeta no nace con la muestra parisina, sino que estuvo presente en la crítica de su obra visual desde sus primeras exhibiciones, en las Ferias del Parque Forestal de 1959 y 1960, donde su obra se caracterizó como ingenua, intuitiva y simple, relacionándose con lo popular y no académico. Dicha concepción le ha impedido hasta hoy ingresar al canon de la historia del arte chilena (Quijada, 2017; Yalkin, 2017; Hormazával, 2013; Reveco, 2011). 
6 Dicha representación de su obra visual prefigura a Violeta Parra como una 'real' exponente de la cultura popular, quien pese a haber expuesto en el Palacio del Louvre, de alguna manera parece haber sido impermeable a la experiencia europea. Este aspecto es evidente en algunos testimonios de sus contemporáneos. Así, la folklorista Margot Loyola recordaba de sus encuentros parisinos:

"Era prácticamente como una campesina que sale de pronto y se enfrenta a un medio que va más allá de su familia, de su gente, de su pueblo. Y se siente como una hormiguita, que cuando baja del vehículo que la lleva a París - ella lo recordaba mucho -, dice 'qué estoy haciendo aquí, Dios mío?, qué ganas de salir arrancando'; pero sentía la necesidad de dar a conocer lo que era Chile y su pueblo." (en Stambuk y Bravo, 2011: p. 116).

7 Por su parte, el intelectual y director de televisión Enrique Bello señalaba:

"Sus características tan chilenas no las abandonaba en ninguna parte. Aunque recibiera toda la influencia europea, a pesar de su contacto con otras realidades, se mantenía latente en ella todo lo auténticamente popular que tenía. Cuando regresó, siguió viviendo acá de la misma manera que antes: no faltaba en su casa el brasero de cobre en la mitad de la pieza ni el aguardiente de Chillán. [...] Ella no fue a París como los señoritos del siglo diecinueve a aprender la última moda, no, ella fue a imponer la canción chilena. Ése era su desafío. Quiso probar, someterse a prueba. Era una tarea dura la de ella, en un lugar del que no conocía el idioma ni las costumbres." (Ibíd.)

8 Patricia Stambuk y Patricia Bravo, quienes recopilaron los citados testimonios en un intenso trabajo de entrevistas realizadas entre 1971 y 1972, concluyen su sección sobre la artista en Europa, en línea con estas citas, afirmando: "Violeta volvió de Europa en junio de 1965, tan pobre como al principio y tan auténtica como siempre.” (Ibíd: p. 133).

9 Más allá de la idea de una Violeta Parra que se encontraría fuera de contexto en el mundo europeo, estas descripciones invisibilizan la posible influencia de las estadías en el extranjero en el propio quehacer artístico de Violeta, no considerando sus intercambios recíprocos con artistas e intelectuales europeos y latinoamericanos, como tampoco la incidencia de sus nuevas experiencias internacionales en su postura social y política. Así, sólo recientemente se han documentado sus exposiciones en Rio de Janeiro (Plante, 2017) y en Berlín Oriental, ${ }^{2}$ mientras que sobre sus exposiciones en Ginebra y otras ciudades de Suiza, mencionadas en cartas recopiladas en El libro mayor (I. Parra, 2015a), no se registran aún investigaciones. Aspectos biográficos más conocidos, como sus viajes a festivales musicales europeos y su relación, desde 1960, con el músico suizo Gilbert Favre, con quien convivió por períodos en Ginebra, también debieran ser explorados como fuentes de intercambios artísticos y culturales. Así, por ejemplo, su hijo Ángel recuerda que la casa de Ginebra se ubicaba en un milieu artístico:

"Allá vivíamos en un callejón muy lindo que tenía una inmensa copa de mimbre al medio. Por un lado, habían puros artesanos en fierro, por el otro, pintores, poetas, escultores... jde todo! Y en el fondo, nosotros." (en Stambuk y Bravo, 2011: p. 123).

10 Si bien en casos de otros artistas chilenos que vivieron, como Violeta, el traslado del campo a la ciudad, como serían Pablo Neruda, Gabriela Mistral o su mismo hermano Nicanor, la procedencia rural no ha impedido su representación como artistas contemporáneos, en el caso de Violeta, la obra musical y visual parece haberse vinculado tan estrechamente con tradiciones populares y técnicas artesanales, que la categorización de 'auténtica' terminó absorbiendo su representación personal en Chile (Cánepa, 2014). 
11 Sin embargo, durante la última década algunas investigaciones han ofrecido alternativas a esta visión, explorando el concepto de la 'autenticidad' y su puesta en escena como una estrategia de posicionamiento de la propia Violeta Parra. Así, Ericka Kim Verba parte de la base de una Violeta cosmopolita que encarna conscientemente valores 'auténticos', en cuanto entiende las expectativas del público parisino en torno a ellos. En relación a la exposición en el Louvre afirma:

“To use Parra's Louvre exhibit as illustration, its French and expatriate Latin American visitors and Parra herself were all members of the same modernistcapitalist cosmopolitan cultural formation. As such, they shared a set of aesthetic sensibilities and social values, including their understanding of authenticity." (Verba, 2013: p. 272).

Desde la visión de Violeta como artista cosmopolita que integraba en su obra elementos provenientes de los diversos espacios culturales en los que se desenvolvía, y que conocía los códigos vinculados a la autenticidad, es posible abrir perspectivas para su estudio sin caer en dualidades esencialistas tales como tradicional-moderno, local-global o popularculto.

13 El trabajo de Verba, que se enfoca principalmente en la producción musical de Violeta Parra, puede complementarse con el estudio de Fernando Ríos sobre los inicios de la música andina en París. El autor igualmente parte de la concepción de un grupo de latinoamericanos cosmopolitas, que concibieron una música propiamente latinoamericana en el marco de su experiencia parisina de la década de 1960 (Ríos, 2008). Por su parte, Serda Yalkin deconstruye el concepto de autenticidad en la obra visual de Violeta Parra, coincidiendo con estos autores en que la audiencia francesa de la época se caracterizaba por un 'anhelo de lo auténtico', motivado por el auge de la industrialización y el capitalismo, como también como consecuencia del acercamiento cultural de Francia hacia los Estados Unidos en la década de 1960 y una reacción de solidaridad anticapitalista hacia el - a partir de entonces así llamado - Tercer Mundo. El término de la colonia francesa en Argelia en 1962 contribuyó también a despertar sentimientos nostálgicos hacia el antiguo mundo imperial. Este interés por el 'otro', dentro del cual la fascinación por lo auténtico, la solidaridad social y una cierta nostalgia colonialista se entrelazan, habría sido el contexto en el cual Violeta Parra y otros artistas latinoamericanos desplegaron su obra en París (Yalkin, 2017).

14 Complementando estas perspectivas, las historiadoras del arte Isabel Plante y Lorna Dillon inscriben la obra visual de Violeta Parra en el marco de desarrollos artísticos propios de la Guerra Fría (Dillon 2009 y 2017, Plante 2017). Mientras que la política cultural norteamericana del período promovía un arte abstracto, el realismo socialista fomentaba el arte figurativo. Como alternativas para un arte figurativo renovado, en Europa surgieron en esta época tendencias tales como el art brut, art naïve, pop-art, neodadaisme y nouveau realisme, que buscaban legitimar una postura anti académica, la figuración no realista y el trabajo con materiales informales. Mientras que Dillon propone una mirada de la obra de Violeta Parra como contemporánea del pop-art y el neodadaisme, poniendo en valor su uso de materiales cotidianos, especialmente en sus obras con papel maché (Dillon, 2017), Plante contextualiza su obra en el desarrollo latinoamericano y pone de relieve que los tránsitos entre la cultura artesanal/popular y el arte moderno, en ambas direcciones, son característicos de las vanguardias históricas. En Chile, Nemesio Antúnez - quien cultivó un intercambio artístico con Violeta - sería un referente importante de estos tránsitos (Plante, 2017). 
15 Recapitulando estas ideas, si bien aún quedan muchos vacíos por investigar en torno a la experiencia europea de Violeta Parra, es posible afirmar que la artista que en 1963 comenzó las negociaciones que desembocarían en una muestra individual en el Palacio del Louvre era una mujer cosmopolita que vivía de su trabajo en Europa, hablaba el francés con bastante fluidez y se movía en un ambiente artístico entre París y Ginebra. De la misma manera que Violeta Parra supo integrar su interés por la cultura popular con los medios de la ciudad moderna, como lo son la radio y la industria discográfica, resignificando prácticas musicales rurales a través de medios cosmopolitas (Verba, 2013), también sería pertinente ampliar el estudio de su obra visual a sus contactos con artistas y artesanos europeos y latinoamericanos, así como ahondar en su conocimiento de tendencias del arte moderno de su tiempo.

\section{El Louvre de Violeta}

16 Inaugurado oficialmente como museo en el Palacio del Louvre en 1793, en el marco de la Revolución Francesa, el Museo del Louvre conserva colecciones de arte europeo y de diferentes culturas del mundo desde la Antigüedad hasta $1848 .{ }^{3}$ Si bien el museo realiza exposiciones temporarias dedicadas a otros artistas o temas, estas no constituyen el foco central de la institución. Cabe entonces preguntarse: ¿en qué categoría hubiera cabido la obra de Violeta Parra en el Museo del Louvre? ¿Como una exposición temporaria de arte moderno? ¿Cómo una muestra de cultura tradicional chilena, vinculada con el pilar etnológico del museo? En este marco, resulta importante precisar que la exposición de Violeta Parra no se realizó en el 'Grand Louvre', sino en el Musée des Arts Décoratifs, institución que ocupa el ala noroeste del Palacio del Louvre y el Pavillon de Marsan, edificio de cinco pisos en el extremo de dicha ala del palacio. El Museo de Artes Decorativas se aloja en el Palacio del Louvre desde 1905, una vez que su anterior ubicación, el Palais de l'Industrie, fuera demolido. Si bien este museo y el Museo del Louvre son albergados por el mismo palacio, constituyen instituciones independientes (Brunhammer, 1992).

17 Algunas cartas conservadas en el archivo del Museo de Artes Decorativas de París demuestran que la llegada de Violeta Parra a esta institución no fue espontánea, sino que la artista, respaldada por sus exposiciones anteriores en Rio de Janeiro, Berlín y Ginebra, estuvo en contacto con el embajador chileno Carlos Morla Lynch, quien primeramente recomendó su obra a Jean Cassou, director del Museo de Arte Moderno de París. ${ }^{4}$ Cassou se encontraba por entonces planificando su exposición de arte ingenuo Le monde des naifs, que comenzaría en octubre de $1964,{ }^{5}$ y como demuestra Isabel Plante, estaba en contacto con intelectuales latinoamericanos residentes en París, lo que se vincula a su cercanía con el comunismo francés. En 1963 había acogido en su museo una exposición de arte argentino actual (Plante, 2017). Por razones no explicitadas en las cartas, Bernard Dorival, también director en el Museo de Arte Moderno, recomendó la obra de Violeta a Michel Faré, director del Museo de Artes Decorativas, destacando que sus arpilleras (broderies) representarían una renovación del arte popular indígena de Chile que le podría interesar.

${ }^{6}$ Como ya se mencionó, Faré puede ser identificado como el principal promotor de la exposición de Violeta en el museo.

18 Desde sus comienzos, el Museo de Artes Decorativas de París ha fluctuado entre las artes aplicadas y las artes plásticas. Junto a objetos de diseño, tapicerías, cerámicas y colecciones de países orientales, el museo también alberga artefactos creados por artistas 
famosos. Sus exposiciones tradicionalmente se concibieron en torno a un tema, región, técnica o período histórico. Sin embargo, en 1955 el museo organizó una gran exposición dedicada a Pablo Picasso, la que tuvo un record de visitantes. Le siguieron exposiciones de otros pintores, escultores y fotógrafos, partiendo por Marc Chagall (en 1959), Jean Dubuffet (en 1960) y Henri Matisse (en 1961). Cabe destacar que los mencionados artistas se relacionan, al igual que Violeta Parra, con una propuesta figurativa que propone perspectivas no academicistas, como en el caso del concepto de 'art brut' acuñado por Dubuffet, que legitima algunos atributos criticados en la obra de Violeta por los críticos chilenos: un arte realizado por autodidactas, al margen de las instituciones artísticas oficiales, que promueve el uso de materiales o técnicas informales. En este contexto, más allá de constatar que la imagen cinematográfica de Violeta ingresando al 'Grand Louvre' no se sustenta históricamente, se podría decir que el Museo de Artes Decorativas de París era probablemente el lugar más indicado para su muestra parisina, ya que brindaba un espacio a artistas que exploraban en técnicas informales y nuevas posibilidades figurativas, en línea con su propia propuesta.

19 Dado este foco en la figura de artistas individuales, el Museo de Artes Decorativas fue reorganizado en la década de 1960, brindando más espacio a exposiciones temporarias por sobre artefactos de diseño industrial, que fueran centrales en sus comienzos. La exposición de Violeta Parra coincidió con la conmemoración del centenario de la institución, durante el cual se realizaron variadas exposiciones. Así, una semana tras la exposición de Violeta se inauguró una muestra de pintores de Argelia, donde se encuentran tanto obras abstractas como figurativas, definidas en el catálogo como naïve. ${ }^{7}$ Como contraparte, la exposición "Nouvelle Tendance", también inaugurada en abril, constituyó una emblemática muestra del arte cinético, con representantes de once países, entre ellos también algunos latinoamericanos residentes en París. ${ }^{8}$

La exposición de Violeta Parra se inauguró el 8 de abril de 1964 junto con "Les Sculptures Musicales des Frères Baschet et les Structures Sonores Lasry-Bachet”. Las exposiciones estaban en salas contiguas del Pavillon de Marsan, lo que posiblemente se haya fundamentado en la relación de ambas con la música.

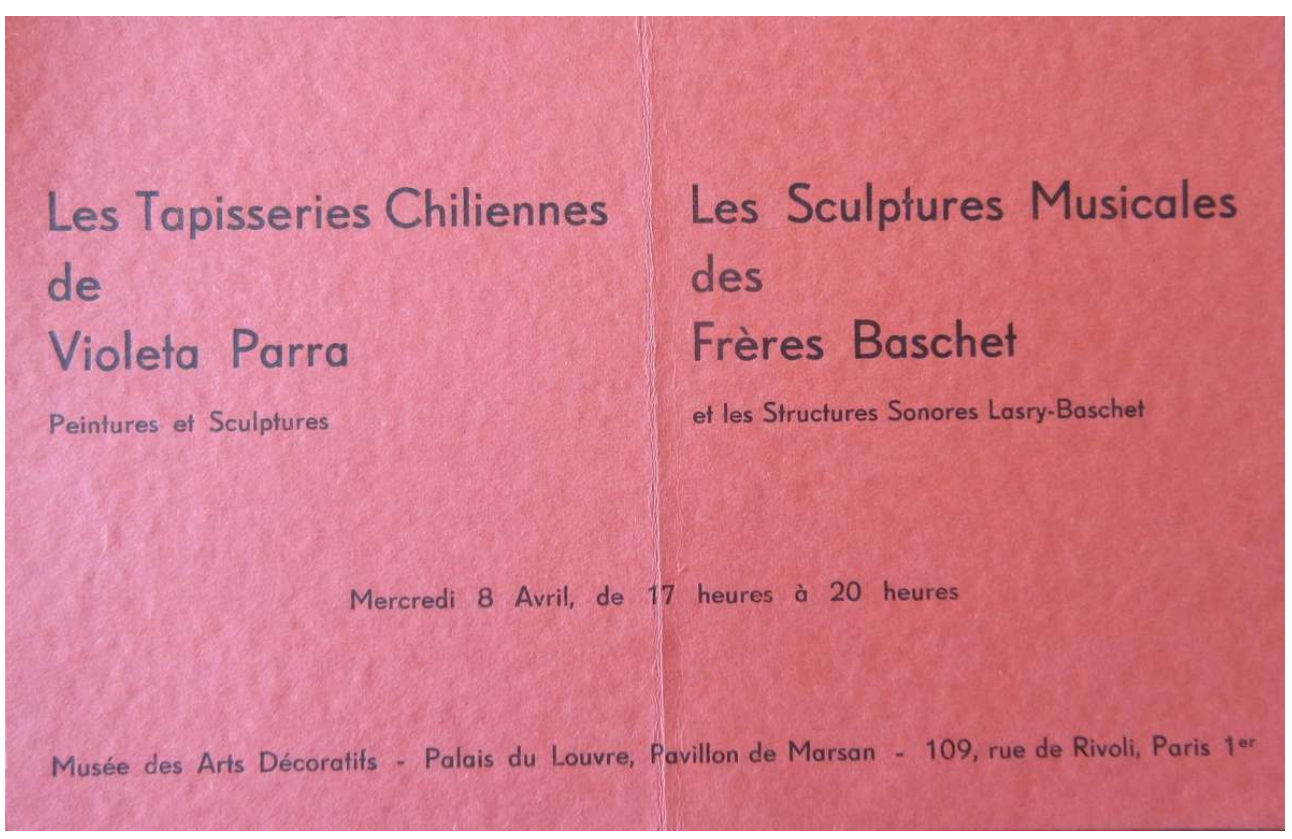

Imagen 2: Invitación a las exposiciones de Violeta Parra y los hermanos Baschet, Bibliothèque du Musée des Arts Décoratifs. 


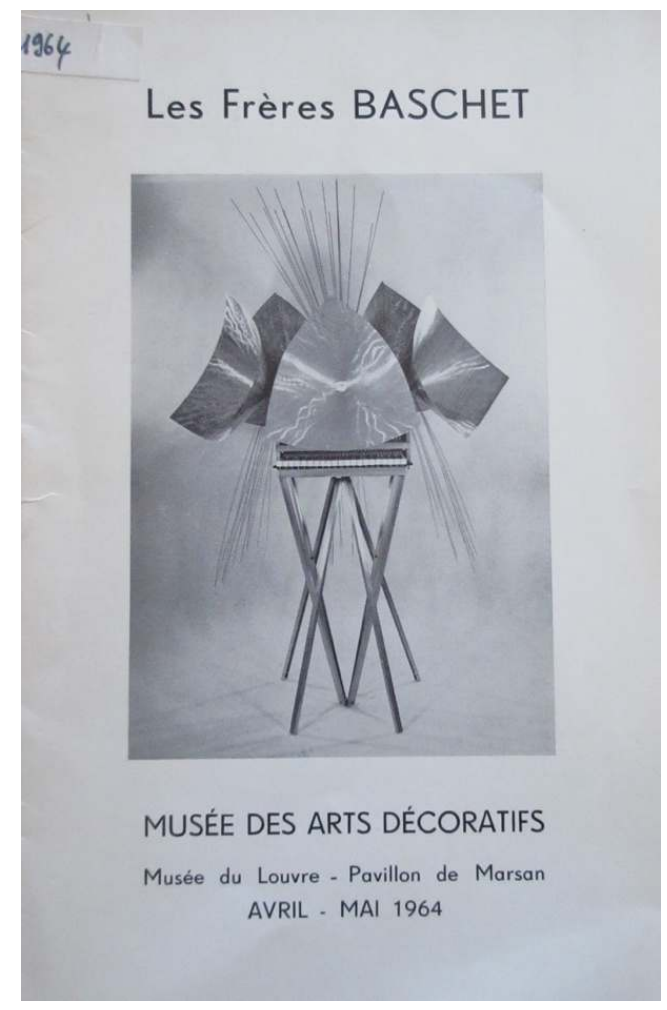

Imagen 3: Portada del catálogo de la exposición de los Baschet, Bibliothèque du Musée des Arts Décoratifs.

21 Los hermanos Baschet, asociados con Jaques e Yvonne Lasry, presentaban en su muestra artefactos musicales vanguardistas. Sus creadores constataban en el catálogo de la exposición que existía un desarrollo actual de instrumentos electrónicos, como el ondes martenot, lo que sin embargo no habría llevado al desarrollo de instrumentos mecánicos contemporáneos. De este modo, preguntaban de manera provocadora: ¿Por qué tocar música del siglo XX con instrumentos del siglo XVIII? Los visualmente sofisticados instrumentos, todos mecánicos y basados en el principio de la vibración, podían ser tocados por los visitantes, generando un espacio interactivo. ${ }^{9}$

22 Mientras que las esculturas sonoras de los Baschet, como la muestra de arte cinético, apuntaban a un arte experimental de orientación internacional, la exposición de Violeta se vinculaba a una expresión culturalmente situada, de manera similar a la exposición de los pintores de Argelia, en consonancia con el ya comentado interés en el Tercer Mundo por parte de la audiencia francesa de la posguerra. Entre los motivos de sus arpilleras, pinturas y esculturas de alambre, se encuentran rituales, prácticas y celebraciones populares (casamientos, entierros, el velorio del angelito, las fiestas patrias chilenas el 18 de septiembre, la artesanía de Quinchamalí), escenas de la vida personal (fiestas en casa de Violeta, máscaras de familiares y amigos, recuerdos del circo de provincia en que trabajara en su infancia), instrumentos y manifestaciones musicales populares (la cueca, los parabienes, el arpa, la guitarra, músicos y vendedores populares), además de algunos motivos de contenido político (Contra la guerra, 1963; La huelga de los campesinos, 1964; El prisionero inocente, s/f) o épico/literario (la leyenda del último rey inca, El árbol de la vida, 1963). Principalmente en el caso de las esculturas de alambre, los motivos no se circunscriben a la cultura chilena, como lo serían animales, Don Quijote o un Cristo crucificado. 
Diversos testimonios mencionan que la exposición de Violeta fue muy exitosa y visitada por numerosas personas, entre ellas diplomáticos y miembros de la alta sociedad parisina, coleccionistas, directores de museos de Italia, Holanda y Bélgica, críticos y artistas, como Roberto Matta (I. Parra, 2015a). Para el día de la inauguración, habría que acotar que una parte del público podría haber llegado atraída por la exposición de los Baschet. La exposición fue documentada con fotografías y un video, donde Violeta Parra se presenta con un sobrio vestido oscuro, rodeada de diversos visitantes (ver en Fundación Violeta Parra, ed., 2007). Si bien algunos estudios mencionan que durante la exposición la artista estaba continuamente presente tocando guitarra, bordando y explicando sus técnicas a los visitantes (Yalkin, 2017; Verba, 2013), estas actividades no se mencionan en las críticas de prensa de la época. Su hija Carmen Luisa, que vivía con su madre en París, recordaba que durante la exposición, su madre pasaba el día en el museo, donde ambas almorzaban juntas la comida que ella llevaba (en Stambuk y Bravo, 2011: p. 127). Por su parte, Enrique Bello menciona que en las exposiciones de Violeta había un ambiente muy vivo, con música chilena, mate y mistela (Ibíd.: p. 128-129). Cabe acotar que el recuerdo de Bello es extensivo a una exposición de Violeta visitada en Ginebra, por lo que resulta difícil precisar las actividades realizadas durante la muestra parisina. El archivo del Museo de Artes Decorativas efectivamente conserva fotografías de Violeta Parra tocando guitarra y cantando junto a las arpilleras expuestas, aunque el contexto en el que se desarrollaron estas actividades, que bien podrían haberse circunscrito al día de la inauguración, es difícil de precisar. ${ }^{10}$

24 El estudio del catálogo de la muestra deja de manifiesto que más de la mitad de las obras expuestas en París corresponden a trabajos actualmente desconocidos de Violeta Parra. Ya que no existe un catálogo razonado de la obra visual de la artista, las obras que han tenido una mayor recepción son las que se encuentran en posesión de la Fundación Violeta Parra, las cuales conforman la colección del Museo Violeta Parra y han sido presentadas en catálogos editados por la Fundación. ${ }^{11}$ Poco se sabe sobre el paradero de las obras que quedaron en Europa, ya sea en colecciones privadas o públicas. Su hija Isabel Parra, directora de la Fundación, menciona que Violeta regaló obras a amigos y diplomáticos en Ginebra. Los óleos habrían quedado en su totalidad en Ginebra tras el regreso de su madre a Chile en 1965, para ser entregados a sus hijos en la década de 1970. Tras la muerte de Violeta en 1967, las obras reunidas en la Carpa de La Reina habrían sido cuidadas por su hermano Nicanor. Con el inicio de la dictadura militar chilena en 1973, las obras conservadas en Chile sufrieron - con los hijos de Violeta - el azaroso destino del exilio, viajando a Francia y Cuba, para regresar a Chile a fines de la década de 1980 (I. Parra, 2015b).

\begin{tabular}{|l|l|l|l|}
\hline Técnica & $\begin{array}{l}\text { Número de obras de acuerdo al } \\
\text { catálogo de 1964 }\end{array}$ & $\begin{array}{l}\text { Catálogos Fundación } \\
\text { Violeta Parra }\end{array}$ & Restantes \\
\hline Afiche (arpillera) & 1 & 1 & 0 \\
\hline Arpillera & 22 & 7 & 15 \\
\hline Pintura & 26 & 17 & 9 \\
\hline $\begin{array}{l}\text { Escultura de } \\
\text { alambre }\end{array}$ & 12 & 0 & 12 \\
\hline
\end{tabular}




\begin{tabular}{|l|l|l|l|}
\hline Total & 61 & 25 & 36 \\
\hline
\end{tabular}

Tabla 1: Obras de la exposición y conservación actual. desconocido, a las que se pueden agregar nuevas obras surgidas tras la exposición, como es el caso de una arpillera sobre el motivo de Fresia y Caupolicán, que pertenece a la colección de la Casa de las Américas en La Habana. ${ }^{12} \mathrm{~A}$ través de fotografías y del video de la exposición, se pueden identificar algunas de estas obras "perdidas". Entre ellas figura la arpillera El Clown de 1960. Esta obra fue exhibida durante el 2017 en el marco de la exposición "Travaux de dames?", realizada también en el Pavillon de Marsan del Museo de Artes Decorativas. Tras consultar con los curadores de la muestra, se me informó que El Clown pertenece a la colección permanente del Museo de Artes Decorativas de París, al que fuera donada por el Sr. Le Bas el 25 de mayo de $1964 .{ }^{13}$ Esta información, que no figura en los catálogos de la obra visual de Violeta Parra, sugiere la probabilidad de que otras obras hayan sido donadas o vendidas a los museos y galerías en los que Violeta Parra expuso su obra.

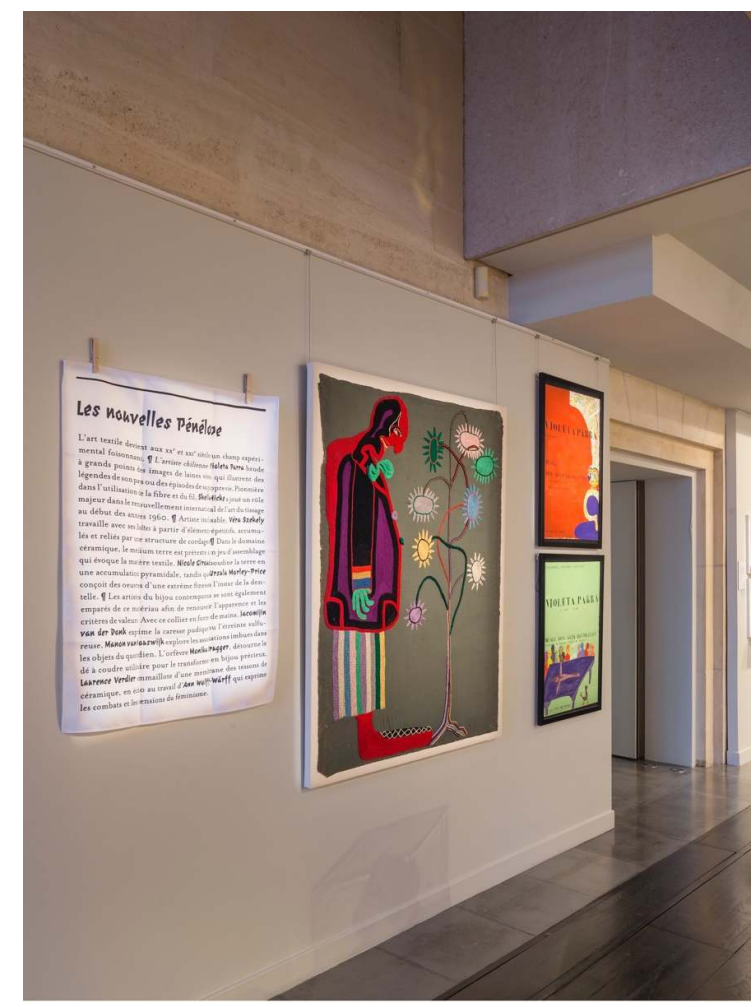

Imagen 4: El Clown (1960), en: Musée des Arts Décoratifs, París, exposición “Travaux de Dames?", 2017, fotografía: Luc Boegly. 
27 En cartas publicadas, Violeta Parra se refiere a la venta de algunas obras por parte de un galerista, entre ellas esculturas de alambre, máscaras y tres arpilleras, una de ellas comprada por el dueño de la galería (I. Parra, 2015a: p. 201-202). Entre los compradores de arpilleras figuran también la baronesa de Rothschild y el aristocrático chileno Arturo Prat (Ibíd: p. 180-182). En otra carta menciona la venta de tres pinturas (Ibíd: p. 184-185). Entre las obras que Violeta menciona, tendrá que hacer nuevamente, figuran dos guitarristas, uno negro y otro amarillo, El manicero (1959/64), El Clown y El pajarito [probablemente Le petit oisseau de Violeta, 1962]. Cabe entonces también la posibilidad de que la artista haya vuelto a realizar algunas de las arpilleras de la exposición, complicando aún más el panorama de la recepción. En las citadas fuentes, Violeta provee algunas direcciones de galeristas, las que junto con las menciones de obras vendidas o regaladas ofrecen pistas para el trabajo, sin duda pendiente, de determinar su conservación en colecciones europeas o latinoamericanas.

28 El Musée des Arts Décoratifs conserva una colección de artículos de prensa de diversos medios franceses y europeos en general. La mayoría de ellos son breves y se limitan a anunciar la exposición. Es evidente que los anuncios se orientan en el comunicado de prensa emitido por el museo. Este documento parte constatando que la artista ya es conocida entre los amantes de la música folklórica, por sus registros de cantos y poemas. Su faceta como artista visual sería menos conocida, pese a que las relaciones entre su arte musical y visual son evidentes:

29 “La musique et les couleurs sont liés pour Violeta Parra qui est passée tout naturellement de l'une aux autres et pense que 'chaque chant est un tableau prêt à être peint'. Sur de la toile de jute, elle brode d'étonnantes images de laines vives que illustrent un chant, un conte, une légende du Chili, racontent la pauvreté du peuple ou encore un épisode de sa propre vie. Ses peintures intenses et graves sont le reflet de sa vie difficile et courageuse. Avec ses sculptures de fil de fer, le réve intervient dans son univers plastique, réve peuplé de colombes et d'oiseaux, de lamas et de taureaux, et de personnages légendaires qu'elle aiment, comme Don Quichotte. Musicienne, poète, peintre et sculpteur, Violeta Parra témoigne ici de la jeunesse et de l'originalité de l'art chilien traditionnel." ${ }^{14}$

30 La cita describe la obra de Violeta Parra con atributos similares a las críticas chilenas ya comentadas, designándola como autodidacta que pasó de un arte a otro con naturalidad. Su obra encierra las características del 'arte ingenuo' al ser designada como vívida, fresca, original, vinculada con el arte tradicional chileno, la pobreza del pueblo de chile y la difícil vida de la misma Violeta.

31 Las críticas de prensa utilizan adjetivos similares, describiendo a Violeta como "chilienne qui avec naiveté et comme mysticisme s'inspire de l'art populaire et des traditions de son pays"15 o como "a little, dark, eager woman, very Indian-looking with a mane of black hair streaming down her back to well below the waist." ${ }^{16}$ De esta manera, se destacan sus lazos con el primitivismo, presentándola a ella misma como una 'otra' inocente, mística e indígena.

32 Por su parte, la crítica contemporánea de esta exposición en Chile tendría que ser objeto de un estudio detallado. En trabajos ya mencionados se ha citado la crítica de Francisco Díaz Roncero tras la inauguración de la exposición, para el periódico chileno de distribución masiva El Mercurio, vinculado a la aristocracia santiaguina:

"Yo he sido uno de los primeros sorprendidos por esa exposición: [...] Violeta Parra comienza en París por donde los grandes del arte terminan, es decir, por exponer sus obras en uno de los pabellones más codiciados por todos los pintores del mundo. 
[...] Al ver los tapices situados en las primeras salas, he comprendido el porqué de ese maravilloso impulso de Violeta Parra, el de llegar a París y presentar objetos fantásticos, simbólicos, con un contenido humano y social, hay un gran arte, sencillo, espontáneo, natural, de quien no sabe de academias ni de estudios. Un arte que capta al que lo ve, que interesa por las variedades de sus colores, por la mezcla de ellos, por la armonía de conjuntos y la gran fuerza de expresión popular."17

Si bien el crítico continúa refiriéndose a la obra de Violeta como un arte simple y espontáneo, inocente y no académico, es evidente que la exposición en París tuvo una positiva incidencia en el crítico, quien destaca el contenido humano y social de las obras, resaltando que se hayan expuesto en "uno de los pabellones más codiciados por todos los pintores del mundo". Justamente esta afirmación podría ser cuestionada, ya que el Museo de Artes Decorativas de París, sin desmedro de su interesante propuesta, difícilmente clasificaría entre los museos más codiciados de los 'pintores' del mundo, dado su perfil móvil entre las artes aplicadas, el diseño industrial y, en menor medida, las bellas artes. Si la afirmación se remitiera a una confusión entre este museo y el 'Grand Louvre', seguiría siendo curiosa, ya que como ya se comentó, el Museo del Louvre nunca se ha especializado en las exposiciones de artistas contemporáneos. En este sentido, la afirmación probablemente apunte al valor del 'Louvre' como símbolo de la alta cultura parisina y europea en general.

34 El hecho de que esta afirmación no parezca haber sido desmentida, sino - al contrario se continúe hablando coloquialmente de Violeta Parra 'en el Louvre', sin mayores exploraciones en el lugar institucional que tuviera la exposición dentro del monárquico palacio francés, puede conectarse con la fascinación de un sector de la sociedad chilena por la cultura europea, la que no nace necesariamente desde un conocimiento profundo, sino más bien desde la imaginación de una otredad, admirada en un gesto colonial que podría leerse como el reverso de la fascinación de los europeos ante el 'primitivismo' de Violeta. Pero aunque en ambos casos el 'otro' causa fascinación sin conocerlo verdaderamente, la relación es asimétrica, ya que es el Louvre, como lugar simbólico, el que legitima la obra de Violeta al transferirle valores asociados con la cultura europea, mientras que Violeta, desde la perspectiva europea, es interpretada con valores subordinados, vinculados a lo inocente, simple y autodidacta.

\section{La técnica de la tapisserie y el 'arte femenino'}

Frecuentemente se ha vinculado la técnica de la arpillera desarrollada por Violeta Parra con el mundo rural chileno, donde su connotación es eminentemente femenina (Cánepa, 2014; Dillon, 2009). Así, si bien existen diversas técnicas, utilizando lana, hilo o retazos de género, en todos los casos las arpilleras son hechas por mujeres. Pero la idea del bordado o la tapicería como actividad femenina trasciende el espacio chileno, como lo demuestra su presencia desde los inicios del Museo de Artes Decorativas de París. 


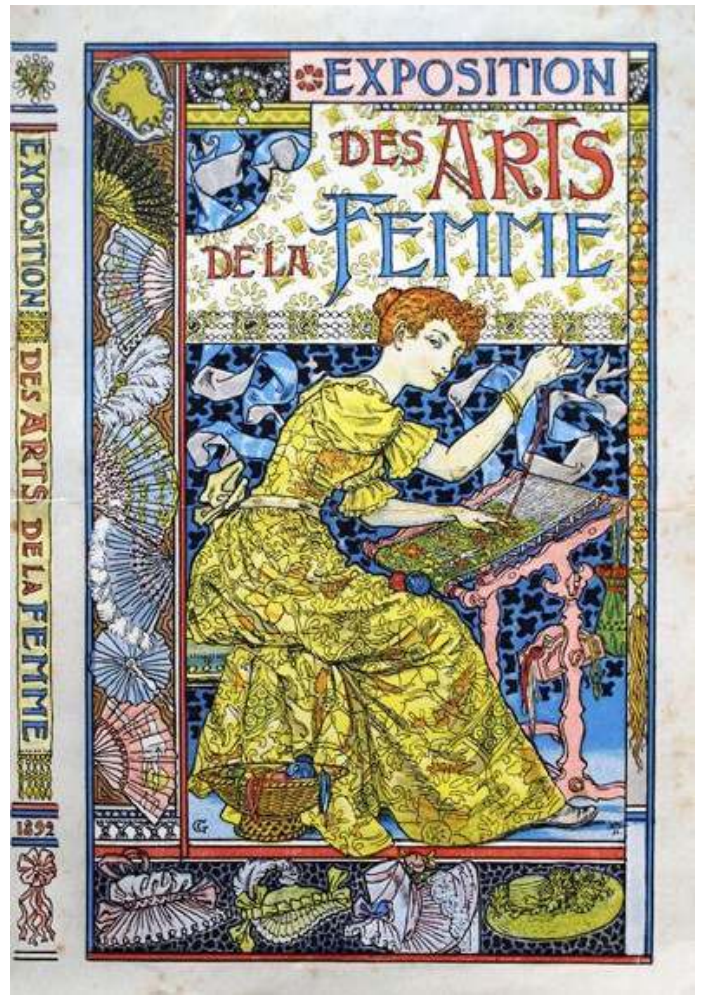

Imagen 5: "Exposition des Arts de la Femme", Palais de l'Industrie, París 1892. Fuente: Gallica, Biblioteca Nacional de Francia.

36 En 1892, la "Exposición des Arts de la Femme" presentaba pinturas, esculturas y diseños hechos por mujeres, además de artefactos de uso femenino, como vestimenta y otros. Más allá de la imagen de una mujer bordadora que representa las 'artes femeninas' en el afiche de la exposición, el catálogo demuestra que un amplio sector estaba dedicado a la tapisserie, existiendo también una sección de 'broderies anciennes'. ${ }^{18}$

Dentro de la ya comentada puesta en escena de la autenticidad en Violeta, la conexión de la artista con un espacio rural femenino es especialmente evidente en su obra visual. Mientras que la Violeta cantautora encarnaba estereotipos tradicionalmente masculinos, presentando al público europeo creaciones propias de agudo contenido social y político, la Violeta de las arpilleras representa una actividad íntima, desarrolla por generaciones de mujeres en el espacio privado. Así, en fotografías y videos, Violeta se muestra bordando sola, vestida de manera sencilla y sin maquillaje, rearticulando la actividad femenina de bordar como acto cotidiano. 


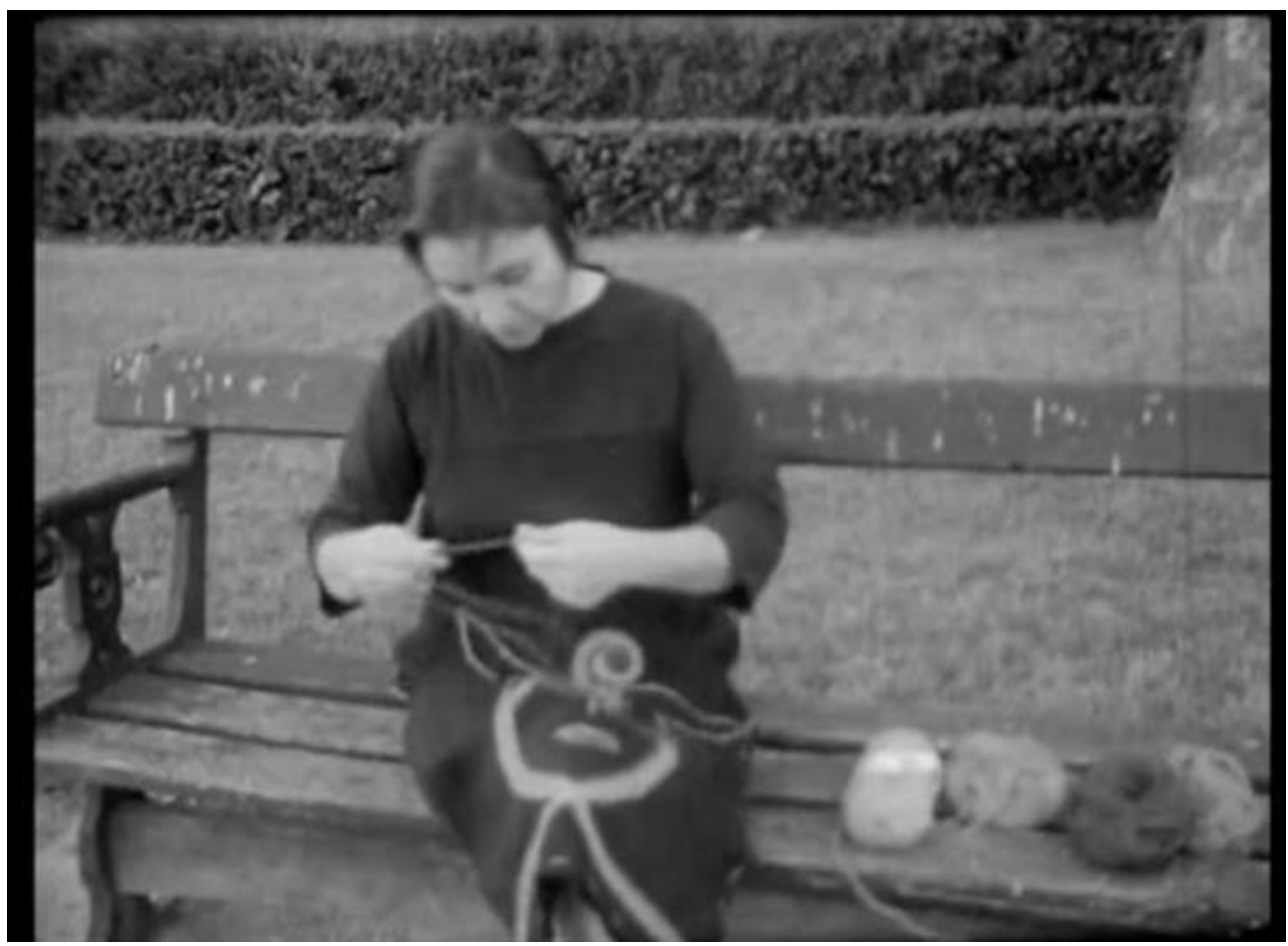

Imagen 6: Violeta Parra borda una máscara. Tomada de un video histórico de la exposición parisina. Fuente: https://www.youtube.com/watch?v=bLm2a_PIWGw (15.11.2018).

En la muy citada entrevista televisiva de Ginebra en 1965 con Marie-Magdeleine Brumagne, titulada justamente como "Violeta Parra, Bordadora Chilena", la artista no sólo recalca el no tener formación académica ni un plan preconcebido para bordar o pintar, sino que se presenta con un vestido hecho con retazos de género, que explica haber sido hecho por su madre. La vestimenta la lleva a mencionar la pobreza de su infancia, donde su madre se veía obligada a coser con los escasos materiales a su disposición. La vida actual de Violeta tendría elementos en común con la vida rural de su madre, al vivir también ella de manera sencilla y creando sus obras con los materiales a su alcance, algunos de estos modestos o cotidianos, como un cubrecamas, alambres y lanas. En la siguiente imagen de la entrevista (imagen 7), Violeta explica otra de las arpilleras de paradero desconocido. En esta representación, la vida cotidiana de Violeta Parra en un barrio de artistas en Ginebra y su conocimiento de la escena artística parisina se invisibilizan, para pasar a encarnar atributos de la mujer popular chilena, su vida esforzada y su capacidad de improvisación en el marco de limitaciones materiales. 


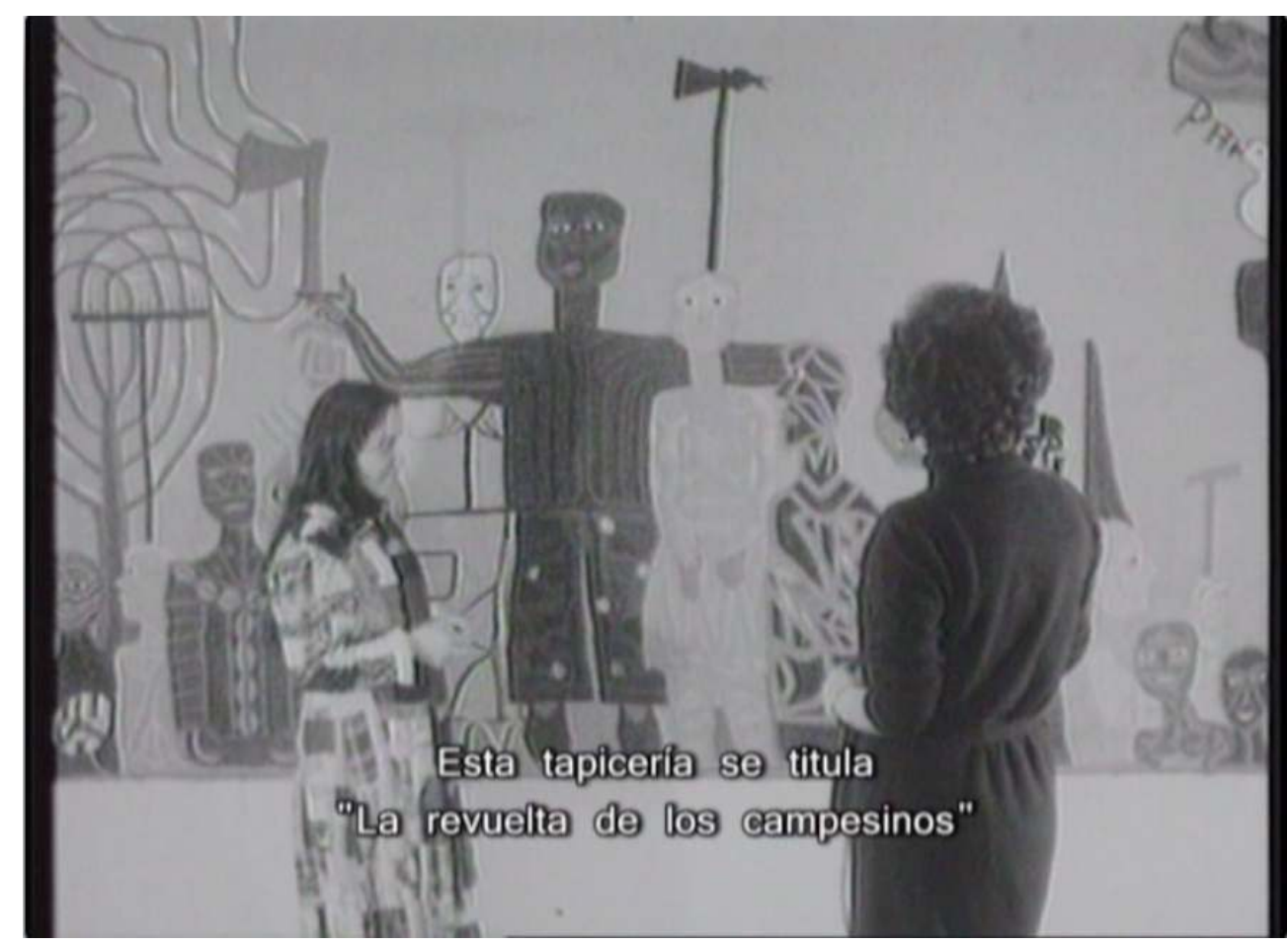

Imagen 7: Violeta Parra en entrevista con Marie-Magdeleine Brumagne, "Violeta Parra, brodeuse chilienne", Ginebra 1965. Fuente: https://www.youtube.com/watch?v=FOeTsevvclY (15.11.2018).

39 En contraste con esta representación femenina, resulta interesante observar que justo antes que Violeta, el artista Jean Lurçat presentó sus propias tapisseries, conocidas como Le chant du monde, en el Museo de Artes Decorativas. ${ }^{19}$ Se trata de diez tapicerías de gran formato - algunas de más de ocho metros de longitud -, que tratan sobre problemas del mundo de posguerra, como la amenaza atómica y la división del mundo en dos bloques, y apelan a la armonía entre los seres humanos. El gran tamaño y la compleja simbología coinciden con el tono profético del mensaje de Lurçat. Sin embargo, sus trabajos tienen en común con las arpilleras de Violeta el ser figurativos, usar colores y figuras (pájaros, agua, personas) de manera simbólica y denunciar la violencia en el mundo - si se piensa en la conocida arpillera de Violeta titulada Contra la guerra (1963), que fue expuesta en 1964 en París -, lo que se condice con que también Lurçat representaba una postura política de izquierda. Pero mientras que Lurçat contaba con un equipo de artesanos en su taller, a quienes él mismo dirigía como lo hubiera hecho un director de orquesta, ${ }^{20}$ Violeta se representaba a sí misma como la artesana que crea espontáneamente en un espacio íntimo. Si Lurçat encarna el ingenium de quien diseña una obra de arte, Violeta encarna el ars, como ejecutora de la técnica manual. Esto también puede extenderse a una contraposición de estereotipos de género, en cuanto el arte de Lurçat es público e intelectual, mientras que el de Violeta es privado y artesanal.

40 La representación de la obra de Violeta como arte femenino es consecuente con la inclusión de la arpillera El Clown en la ya mencionada exposición "Travaux de dames?" (2017) en el Museo de Artes Decorativas de París, la que partió de la premisa de que este museo fue pionero en tematizar el lugar de las mujeres en las artes aplicadas. ${ }^{21} \mathrm{Sin}$ embargo, más allá de la representación propulsada por la misma Violeta en entrevistas, videos y fotografías, se podría afirmar que la artista no representaba los atributos relacionados tradicionalmente con lo femenino. En los 1960s, era una mujer cosmopolita que mostraba sus creaciones musicales y visuales en espacios públicos; además era 
económicamente independiente, si bien de manera modesta, e incluía a sus hijos y nieta en sus proyectos profesionales-musicales. Por otra parte, y como destaca Lorna Dillon en su análisis de las arpilleras, si bien estas obras constituyen un espacio de mediación entre el mundo popular, la esfera femenina doméstica y el espacio público, las obras rompen con convenciones del arte femenino, al no usar colores reales, sino fuertes colores modernistas. Violeta tampoco representa motivos íntimos, como lo serían flores o frutas, sino que sus arpilleras son portadoras de una simbología compleja y un evidente contenido social (Dillon, 2009).

41 Así por ejemplo, en el caso de la arpillera La cantante calva (1960) el catálogo de 1964 explica que la obra representa una fiesta en casa de Violeta, donde ella canta y su hija Isabel toca el arpa, acompañadas de la pequeña hija Cristina y un perro. ${ }^{22}$ En alto se ven cerámicas modeladas por la misma Violeta. El motivo narrado - dos mujeres animando con canto y música una fiesta - coincide con una actividad realizada tradicionalmente por mujeres en Chile, mientras que la mención a las cerámicas, que con sus contornos negros aluden a la artesanía de Quinchamalí en el sur de Chile, representa a Violeta como artesana. Los colores sin embargo no son realistas, como tampoco lo son las figuras. Especialmente llama la atención la representación de las cerámicas como seres animados, que probablemente canten junto a Violeta y su hija. Así, al incorporar alusiones de su vida privada y familiar, tradiciones populares, elementos modernistas y técnicas de la vida cotidiana, Violeta rompe con la oposición dialéctica entre lo público y lo privado, el arte popular y el arte académico, un arte femenino y un arte masculino. Su hermano Nicanor Parra parece haber compartido esta visión rupturista de la obra. Como señala el catálogo de la exposición, fue él quien bautizó la arpillera. El título se toma de la obra de teatro de Eugène Ionesco La cantante calva (1950), vinculada al teatro del absurdo, a la que su mismo autor designaba como una parodia a un teatro burgués, de boulevard: "un teatro de boulevard que se descompone y se vuelve loco" (en Bourdieu, 2010: p. 184). En este caso, sería la fiesta popular la que "se vuelve loca", adoptando elementos vanguardistas y cercanos al surrealismo.

\section{Reflexiones finales}

“el mundo del arte es un juego en el cual lo que está en juego es la cuestión de saber quién tiene derecho de decirse artista y, sobre todo, de decir quién es artista" (Bourdieu, 2010: p. 25).

¿Qué lugar ocupa la exposición en el Palacio del Louvre dentro del proyecto artísticocultural de Violeta Parra? Aunque su prematura muerte interrumpió el ambicioso proyecto en la Carpa de La Reina, existen indicios para afirmar que la exposición en París era entendida por la artista como un hito que podría ayudarla en la materialización de sus proyectos en Chile. Sin duda, Violeta era consciente de la repercusión que el éxito de esta exposición podría tener en su país. Su hijo Ángel recordaba que ella habría reiterado: "esto lo hago para Chile, no para ustedes" (A. Parra, 2006: p. 177). En una carta a Gilbert en 1963, Violeta misma señalaba, también en relación a la exposición:

"Yo quiero que mi nombre crezca para ser más fuerte y más importante para defender mejor mi pueblo. Para batallar contra la burguesía hay que ser fuerte, y yo quiero volver a Chile con nuevo motor. Si se tratara sólo de problemas caseros todo sería muy simple, pero hay un país que espera mi trabajo y el tuyo" (I. Parra, 2015a: p. 177). 
entendía la exposición como un acto de legitimación ante la audiencia chilena:

"Thus, the more authentic the French art world deemed Parra, the more it strengthened and reified her own construction of authenticity, knowing that a positive European reception and view of Chilean traditions might convince her native audience of the validity of her quest." (Yalkin, 2017: p. 49).

44 En esta línea, una última carta de Michel Faré, dirigida a Eugenio González, rector de la Universidad de Chile, destacaba que la exposición de Violeta Parra fue un gran éxito, aclamado de manera unánime por la prensa, mientras que otros museos extranjeros ya estarían interesados en presentar la muestra. Actualmente la artista estaría planificando una gran arpillera épica sobre la historia de Chile. Faré concluye recomendando encarecidamente apoyarla en sus futuros proyectos. ${ }^{23}$ Que la artista gestionara esta recomendación específicamente para el rector de la Universidad de Chile, una de las instituciones centrales para la vida cultural 'oficial' del país, demuestra que para Violeta era importante lograr un reconocimiento a nivel institucional chileno, lo que quizás esté relacionado con el hecho de que a partir de 1964 la obra visual de Violeta, especialmente las nuevas arpilleras, representen episodios de la historia de Chile, como el combate naval de Iquique y la colonización española en el sur.

45 Es evidente que París, en la década de 1960, continuaba siendo un referente central para artistas e intelectuales latinoamericanos, como lo fuera desde el siglo XIX para las oligarquías latinoamericanas, por lo que una exposición en el Palacio del Louvre contribuiría a legitimar el valor de la obra visual de Violeta. Sin embargo, habría que ahondar en el significado de este valor, ya que - en el marco de su puesta en escena de la autenticidad - Violeta Parra no se presentaba en el Louvre explícitamente como artista contemporánea, sino más bien encarnando a la mujer rural, representante de la cultura popular de su país y sus técnicas artesanales femeninas. En ese gesto de 'transformación', Violeta Parra logró que una expresión cultural presentada como espontánea, ingenua y vinculada a los sectores más pobres de su país, ingresara al Louvre, poniendo en conocimiento del público parisino - como también posteriormente en la televisión suiza la riqueza de esta cultura y las difíciles condiciones materiales de vida de las clases populares de Chile. Y si era posible que la cultura popular chilena 'invadiera' simbólicamente el Louvre, entonces también podría 'invadir' Chile.

Considerando que Violeta Parra se refirió a la exposición en la citada carta a Gilbert como una manera de "batallar contra la burguesía", se podría decir que la estrategia legitimadora no apuntaba a los artistas e intelectuales chilenos, muchos de los cuales valoraron su proyecto artístico-cultural en vida de la artista, sino a la burguesía chilena, de la cual Violeta siempre fue una aguda crítica. Es posible que Violeta Parra haya compartido la visión de su compatriota, el poeta y dibujante Alberto Rojas Giménez, quien viviendo en Europa en 1930, ironizaba sobre los chilenos adinerados que visitaban París para impregnarse superficialmente de la 'alta cultura':

"Las anécdotas abundan. Al millonario que viene a darse una vuelta por Europa, que entra al Louvre y dice 'Oh!' delante de la Gioconda, porque así lo estipula el manual del perfecto turista, suele despertársele el pecaminoso deseo de adquirir objetos de arte que lleven en recuerdo de París hasta la casa solariega. [...] Un compatriota que goza de un gran prestigio de 'amateur', en Santiago, me confesó un día sus intenciones de comprar algunas telas de arte moderno. [...] Fuimos a una galería y se decidió a adquirir una tela de Braque, con la condición de que el 'marchand', le 
diera una explicación de lo que la tela significaba, para pegarla al dorso del marco"

(Rojas, 1930: p. 27).

47 La irónica mención alude a un sector no intelectual de la clase dominante chilena, para el cual el Louvre o el arte moderno supondrían un símbolo de estatus, sin haber una intención real de conocer y descifrar sus códigos culturales. En la crónica de Rojas Giménez, la vida materialmente restringida de los artistas chilenos y latinoamericanos en París contrasta con las visitas parisinas de este sector burgués, que es el que tiene los medios para vivir cómodamente su estadía parisina. Probablemente Violeta era consciente de que la burguesía chilena valoraría su exposición en el Louvre en un gesto colonialista, dentro del cual el significado profundo de la exposición y los detalles del museo en que se realizó la muestra no serían centrales. Esta reacción parece confirmarse cuando la citada crítica del Mercurio presenta al Louvre elogiosamente como "uno de los pabellones más codiciados por todos los pintores del mundo" y un lugar "donde los grandes del arte terminan", sugiriendo un rol canonizador del museo en materia de arte contemporáneo, que nace tanto desde la desinformación como desde la superficial admiración hacia la 'alta cultura' europea.

48 También es posible que Violeta haya mantenido una postura crítica ante la escena artística parisina de su época, similar a la que profesara su amigo, el poeta Pablo de Rokha, quien en su última obra, Mundo a Mundo (1966), denunciaba a una Francia colaboradora del capitalismo norteamericano y el consumismo, donde el cosmopolitismo burgués invisibilizaba el valor de la vida en las provincias y las injusticias sociales, cantando a París:

"levanto mi poema humano, enarbolándolo a la altura de tu pueblo inmortal, y azoto la cara cansada y ensangrentada de la gran burguesía, traidoramente cosmopolita, con la épica social americana, afronto lo heroico popular, surgiendo de los asfaltos ametrallados de las gigantes masacres bestiales de la población obrera [...]" (de Rokha, 1966: s/p).

49 En su lucidez ante las desigualdades sociales de su tiempo, Violeta Parra supo hábilmente conquistar un espacio admirado por la burguesía de su país, y encarnando los atributos de una mujer popular, con su vida difícil, su manejo de técnicas y tradiciones populares, supo hacer ingresar estos temas en un espacio connotado como cúspide de la cultura europea. En este sentido, la exposición podría ser interpretada como una provocación simbólica, que rompía con convenciones culturales y de género, pero la provocación no estaba primordialmente dirigida a los visitantes europeos, para quienes la muestra estaría alineada con el interés en el Tercer Mundo y en el 'arte inocente' característico de la década de 1960, sino principalmente a la burguesía chilena. Al tomar sus propios códigos colonialistas y transformarlos positivamente en una legitimación de su obra, Violeta legitimaba el valor de la cultura popular de Chile.

Si bien Violeta Parra efectivamente logró recibir atención de la audiencia chilena y sigue siendo recordada como la primera artista latinoamericana que expuso 'en el Louvre', podría concluirse que su estrategia de legitimación no fue del todo exitosa, ya que su figura quedó en Chile tan fuertemente asociada a la cultura popular, que su obra y su actitud transgresora han quedado relegadas a la categoría de 'arte inocente' o 'auténtico', lo que ha limitado el estudio de su obra visual en toda su profundidad estética, social y política. 


\section{BIBLIOGRAFÍA}

BOURDIEU, P. (2010), El sentido social del gusto. Elementos para una sociología de la cultura, Siglo Veintiuno, Buenos Aires.

BRUNNHAMMER, Y. (1992), Le Beau dans l'Utile. Un musée pour les arts décoratifs Yvonne, Gallimard, París.

CANEPA, G. (2014), "Violeta Parra's Arpilleras: Vernacular Culture as a Pathway to Aesthetic Selfdetermination", en Stitching Resistance. Women, Creativity, and Fiber Arts, ed. Marjorie Agosín, Solis Press, Wellesley College, p. 181-199.

DE ROKHA, P. (1966), Mundo a Mundo. Epopeya popular realista. Estadio primero: Francia, Multitud, Santiago de Chile.

DILLON, L. (2017), “Violeta Parra's Contribution to the1960s Art Scene”, en Violeta Parra. Life and Work, ed. Lorna Dillon, Tamesis, Woolbridge, pp. 157-172.

DILLON, L. (2009), “Defiant Art: The Feminist Dialectic in Violeta Parra's Arpilleras”, en Identity, Nation, Discourse: Latin American Women Writers and Artists, ed. Claire Taylor, Cambridge Scholars, Newcastle, pp. 53-66.

FUNDACIÓN VIOLETA PARRA (ed.) (2007), Violeta Parra. Obra visual, Ocho libros, Santiago de Chile.

HORMAZÁBAL, V. (2013), La obra visual de Violeta Parra. Un acercamiento a sus innovaciones conceptuales y visuales a través del análisis iconográfico de arpilleras y óleos, Tesis de Licenciatura en Artes, Departamento de Teoría e Historia del Arte, Universidad de Chile, Santiago de Chile.

MUSEO VIOLETA PARRA (ed.) (2015), Catálogo Exposición Permanente. Violeta, humana y divina, Santiago de Chile. http://agenciafelicidad.cl/mvp/wp-content/uploads/2017/12/CPMVP0007.pdf

PARRA, Á. (2006), Violeta se fue a los cielos, Catalonia, Santiago de Chile.

PARRA, I. (2015a), El libro mayor de Violeta Parra, Chabe Producciones, Santiago de Chile.

PARRA, I. (2015b), “El viaje de las obras”, en Catálogo Exposición Permanente. Violeta, humana y divina, ed. Museo Violeta Parra, Santiago de Chile.

PLANTE, I. (2017), “Violeta Parra, brodeuse chilienne. La exposición parisina de su obra visual en 1964", ponencia para el primer Coloquio Internacional Violeta Parra, Santiago de Chile, manuscrito.

QUIJADA, F. (2017), “Ni primitiva, ni ingenua: Contemporánea. Reflexiones en torno a la obra visual de Violeta Parra y su recepción crítica", en Consejo Nacional de la Cultura y de las Artes (ed.), Violeta Parra. Después de vivir un siglo, Observatorio Cultural, Santiago de Chile.

REVECO, C. (2011), Historiografía y crítica de arte: Análisis histórico del binomio conceptual artista / artesano. El caso del trato discursivo de la faceta plástica de Violeta Parra, Tesis de Licenciatura, Facultad de Filosofía y Educación, Pontificia Universidad Católica de Valparaíso, Valparaíso. 
Ríos, F. (2008), "La Flûte Indienne: The Early History of Andean Folkloric-Popular Music in France and its Impact on Nueva Canción”, en Latin American Music Review 29 (2), Austin, pp. 145-189.

ROJAS, A. (1930), Chilenos en París, La novela nueva, Santiago de Chile.

STAMBUK, P. / BRAVO, P. (2011), Violeta Parra. El canto de todos, Pehuén, Santiago de Chile.

VERBA, E. K. (2013), “To Paris and Back: Violeta Parra's Transnational Performance of Authenticity”, en The Americas 70 (2), Washington, pp. 269-302.

YALKIN, S. (2017), Folk, the Naïve and Indigeneity: Defining Strategies in Violeta Parra's Visual Art, Tesis de Master of Arts. Art History, Departamento de Arte e Historia del Arte, University of New Mexico. http://digitalrepository.unm.edu/cgi/viewcontent.cgi? article $=1059 \&$ context $=$ arth_etds

\section{ANEXOS}

\section{Archivos}

BIBLIOTECA DEL MUSEO DE ARTES DECORATIVAS DE PARÍS.

\section{Fuentes audiovisuales}

FUNDACIÓN VIOLETA PARRA (ed.) (2007), Violeta Parra. Obra visual, Ocho libros, Santiago de Chile. Material audiovisual de la exposición de 1964, adjunto al libro.

WOOD, A. (2011), Violeta se fue a los cielos, largometraje, Chile, Argentina, Brasil.

\section{NOTAS}

1. Resultados parciales de esta investigación fueron presentados en el Congreso Regional de la Sociedad Internacional de Musicología "Music as Art, Artefact and Fact. Music Research in the 21st Century", Stavanger, 05.07.2016; y en el Primer Coloquio Internacional Violeta Parra, Santiago de Chile, 30.08.2017. Este artículo se nutre de valiosas discusiones surgidas con colegas en ambas instancias.

2. Agradezco a Javier Rodríguez Aedo por la documentación de la exposición en Berlín Oriental en el pabellón del Berliner Verlag, en la Friedrichstrasse, en septiembre de 1962. En el marco de su tesis doctoral, "Production et réception de la musique populaire chilienne en Europe, après le coup d'État militaire (1973-1989)" (Universidad Paris-Sorbonne IV), Rodríguez estudia la recepción de la obra de Violeta antes de 1973 en Europa, la que prefigura la recepción de la música chilena del exilio.

3. Informaciones de su sitio institucional, <www.louvre.fr >.

4. "Par ailleurs, Mme Violeta Parra est créatrice de tapisseries, de peintures et de céramiques d'inspiration populaire. En outre de ses nombreuses expositions au Chili, elle a participé aux côtés des peintres les plus renommés du Chili à une exhibition représentative de l'art pictural chilien réalisée au Musée d'Art Moderne de Rio de Janeiro, oú ses oeuvres ont été chaleuresement accueillies par la critique. Elle a également effectué des Expositions individuelles à Genève et à Berlin, où la critique a été unanimement favorable à ses créations." Carlos Morla Lynch, carta a Jean Cassou, Directeur du Musée d'Art Moderne, París [copia sin fecha]. Archivo, Musée des Arts Décoratifs, París.

5. Exposición “Le Monde des Naifs”, Musée National d'Art Moderne, París, 14.10.-6.12.1964. 
6. Bernard Dorival, Conservateur du Musée National d'Art Moderne, carta a Michel Faré, Conservateur en chef du Musée des Arts Décoratifs, París, 01.10.1963, Archivo, Musée des Arts Décoratifs, París.

7. Exposición “Peintres algériens”, Musée des Arts Décoratifs, París, 15.0.4-30.04.1964.

8. Exposición "Propositions visuelles du mouvement international. Nouvelle Tendance", Musée des Arts Décoratifs, París, abril-mayo 1964. Véase también Plante, 2017.

9. Catálogo de la exposición: Musée des Arts Décoratifs, Les Freres Baschet, Abril-mayo 1964.

10. Imágenes conservadas en los álbumes de fotografías Maciet, de libre acceso en la biblioteca del Museo de Artes Decorativas de París.

11. Fundación Violeta Parra (ed.), 2007; Museo Violeta Parra (ed.), 2015. El catálogo de 1964 puede consultarse en: < http://museovioletaparra.cl/cedoc/violeta-parra-museo-de-artesdecorativas/ >.

12. Obra visitada personalmente por la autora en 2014 .

13. Comunicación por email con Karine Lacquemant, 11.06.2018 y 15.06.2018, a quien agradezco sus amables diligencias. La presencia de esta obra en la exposición de 2017 en París fue mencionada en: Gabriela García, “Lo que dejó Violeta Parra en París”, El Mercurio, 09.07.2017.

14. Musée des Arts Décoratifs, Service de presse, "Les tapisseries chiliennes de Violeta Parra. Peintures et Sculptures”, Palais du Louvre, Pavillon de Marsan, 8.4.-11.5.1964, archivo, Musée des Arts Décoratifs.

15. Le concours médical, 02.05.1964, archivo, Musée des Arts Décoratifs.

16. Phyllis Jenkins, "What will the Weather Be Like in June?", The Glasgow Herald, Glasgow, 24.04.1964, archivo, Musée des Arts Décoratifs.

17. Francisco Díaz Roncero, El Mercurio, Santiago de Chile, 08.04.1964.

18. Catálogo "Exposition des Arts de la Femme", Palais de l'Industrie, París 1892, Biblioteca Nacional de Francia, en: < gallica.bnf.fr >.

19. Jean Lurçat, "Le Chant du Monde et oeuvres récentes", Musée des Arts Décoratifs, eneromarzo 1964.

20. El artista utiliza esta metáfora en una entrevista citada en el catálogo: Jean Lurçat, Musée d'Art et d'Histoire Genève, 10.03.-21.04.1963: p. 6.

21. Véase < http://madparis.fr/en/about-us/exhibitions/recent-exhibitions/travaux-de-dames/ $>$.

22. Esta obra puede verse en el catálogo de la exposición permanente del Museo Violeta Parra, http://agenciafelicidad.cl/mvp/wp-content/uploads/2017/12/CPMVP0007.pdf.

23. "Elle mérite tous les encouragements que très certainement vous ne manquerez pas de lui apporter." Michel Faré, director del Museo de Artes Decorativas de París, carta a Eugenio González, rector de la Universidad de Chile, París, 15.05.1964. Archivo, Musée des Arts Décoratifs.

\section{RESÚMENES}

La exposición “Tapisseries Chiliennes de Violeta Parra. Peintures et sculptures”, realizada entre el 8 de abril y el 11 de mayo de 1964 en el Museo de Artes Decorativas de París, supone un hito en la trayectoria de la artista chilena Violeta Parra, quien es frecuentemente designada como la primera latinoamericana que expusiera individualmente en el Louvre. Pese a esto, sólo recientemente este evento ha sido objeto de investigaciones. El artículo sitúa históricamente la 
exposición y sus representaciones simbólicas, vinculadas a concepciones de un arte ingenuo y femenino, y ahonda en su contexto institucional: el Museo de Artes Decorativas, institución que de manera similar a la obra de la artista - ha oscilado entre las 'bellas artes' y las artes aplicadas.

The exhibition "Tapisseries Chiliennes de Violeta Parra. Peintures et sculptures" that took place from April 8 to Mai 11, 1964 at the Museum of Decorative Arts in Paris, constitutes a milestone in the artistic trajectory of the Chilean artist Violeta Parra, who has been frequently described as the first Latin-American artist to have an individual show at the Louvre. Despite of this, the event has only recently become object of academic research. The article situates the historical implications and symbolical representations of the exhibition, linked to conceptions of a naïve and feminine art. The institutional context - the Museum of Decorative Arts - is explored as an institution that, like Violeta's visual work, fluctuates between the fine arts and the decorative arts.

ÍNDICE

Keywords: tapisserie, embroidery, Violeta Parra, Louvre, decorative art, feminine art.

Palabras claves: tapisserie, arpilleras, Violeta Parra, Louvre, artesanía, arte femenino.

\section{AUTOR}

\section{DRA. DANIELA FUGELLIE}

Profesora de musicología. Instituto de Música. Universidad Alberto Hurtado, Santiago de Chile Dfugellie(at)uahurtado.cl 